\title{
Effects of rumen-protected glutamate supplementation during the periparturient period on digestibility, inflammation, metabolic responses, and performance in dairy cows
}

\author{
S. Hisadomi, ${ }^{1} \odot$ A. Haruno, ${ }^{2}$ T. Fujieda, ${ }^{2}$ T. Sugino, ${ }^{3} \oplus$ and M. Oba ${ }^{1 *} \odot$ \\ ${ }^{1}$ Department of Agricultural, Food and Nutritional Science, University of Alberta, Edmonton, AB, Canada T6G 2P5 \\ ${ }^{2}$ Ajinomoto Co. Inc., Tokyo, Japan 104-8315 \\ ${ }^{3}$ Graduate School of Integrated Sciences for Life, Hiroshima University, Higashi-Hiroshima, Japan 739-8528
}

\begin{abstract}
The objective of this study was to evaluate the effects of feeding rumen-protected glutamate during the periparturient period ( $\mathrm{d}-21 \pm 3$ to $\mathrm{d} 21 \pm 3$ relative to calving) on apparent total-tract digestibility (ATTD), inflammation, metabolic responses, and production performance of dairy cows. Fifty-two multiparous Holstein cows were blocked by parity, body condition score, and expected calving date, and randomly assigned to one of the experimental diets with rumen-protected monosodium glutamate (RP-Glu; intestinally available Glu $=8.8 \%$ ) or without RP-Glu (control) at d $-21 \pm 3$ relative to expected calving date. The RP-Glu was fed at $4 \%$ and $3 \%$ of dietary dry matter, before and after calving, respectively. Prepartum diets contained $17.1 \%$ and $16.5 \%$ crude protein, and $13.1 \%$ and $13.3 \%$ starch, and postpartum diets contained $18.8 \%$ and $18.3 \%$ crude protein, and $22.5 \%$ and $22.7 \%$ starch on a dry matter basis, respectively for RP-Glu and control treatments. A subset of 19 cows was used to measure ATTD. Cows fed the RP-Glu had greater ATTD of dry matter (70.6 vs. $69.1 \%$ ), crude protein (75.1 vs. $72.6 \%$ ), and ether extract ( 66.0 vs $61.2 \%$ ) on d $5 \pm 1$ after calving. Cows fed the RP-Glu also had greater dry matter intake ( 15.7 vs. $13.7 \mathrm{~kg} / \mathrm{d})$ on $\mathrm{d} 1$ after calving. Cows fed the RP-Glu had greater plasma concentrations of Glu (4.60 vs. $3.89 \mu \mathrm{mol} / \mathrm{dL}$ ) and insulin-like growth factor-1 ( 44.2 vs. $30.1 \mathrm{mg} / \mathrm{mL}$ ), lower serum concentrations of free fatty acids (670 vs. $981 \mu \mathrm{Eq} / \mathrm{L})$ and total bilirubin (0.22 vs. $0.34 \mathrm{mg} / \mathrm{dL}$ ), and lower plasma 3-methylhistidine concentration $(1.28$ vs. $1.50 \mu \mathrm{mol} / \mathrm{dL})$ on $\mathrm{d} 4$ after calving. However, these treatment effects observed between d 1 and d $5 \pm 1$ immediately after calving did not continue until d 21 after calving. Concentrations of serum amyloid A, serum haptoglobin, and plasma lipo-
\end{abstract}

Received September 30, 2021.

Accepted November 29, 2021.

*Corresponding author: moba@ualberta.ca polysaccharide binding protein were not affected by the treatment. In addition, no differences were observed for serum $\beta$-hydroxybutyrate concentration and milk yield during the postpartum period between the 2 groups, and cows fed the RP-Glu had a decreased lactose yield. These findings suggest that feeding RP-Glu during the periparturient period can increase digestive capacity and feed intake, and decrease mobilization of body fat and protein immediately after calving without increasing milk production.

Key words: glutamate, calving transition, digestibility, inflammation, dry matter intake

\section{INTRODUCTION}

Nutrient requirements of dairy cows increase with the onset of lactation (NRC, 2001). The nutrients are required for not only lactation but also gastrointestinal growth (Johnson et al., 1990). Mass of the gastrointestinal tract tissues increases after calving, which is likely to be promoted by increased feed intake (Reynolds et al., 2004). In addition, dairy cows can experience gastrointestinal barrier dysfunction, which can be caused by reduced feed intake (Pearce et al., 2013; Kvidera et al., 2017) around the calving. Compromised gastrointestinal integrity and barrier dysfunction can induce gut-derived inflammation (Pearce et al., 2013; Bradford et al., 2015). Previous studies report inflammation related to SARA (Emmanuel et al., 2008; Khafipour et al., 2009a,b) occurs during the calving transition period (Knoblock et al., 2019), but nutritional management to mitigate inflammation during the calving transition period has not been extensively studied.

In addition, dairy cows often experience negative energy balance as the glucose requirement for lactose synthesis in the mammary gland increases with the onset of lactation (Baumgard et al., 2017), and feed intake increases gradually. Transition dairy cows mobilize body fat to cover the negative energy balance, which elevates circulating free fatty acids (FFA) and 
BHB concentrations. However, excess circulating FFA and BHB increase the incidence of metabolic disorders, which results in reduced milk production (Drackley, 1999). Supplying glucogenic precursors could reduce the synthesis of ketones and increase milk production (Aschenbach et al., 2010).

Nonessential AA such as Glu can be synthesized in the animal body (Burrin and Stoll, 2009; Wu, 2013), and their dietary requirements are not established for dairy cows (NRC, 2001). However, Glu is recognized as a primary energy source in the small intestine in swine (Reeds et al., 2000; Burrin and Stoll, 2009) and cows (El-Kadi et al., 2009). Supplementing Glu in the diet of weaning piglets increased small intestinal villus height (Wu et al., 2012) and absorptive capacity of the small intestine (Rezaei et al., 2013). In addition, Glu contributes to the intestinal mucosal barrier function by enhancing cell growth and maintaining membrane integrity (Jiao et al., 2015), and increases antioxidant function (Yin et al., 2015) in swine. Furthermore, Glu contributes up to $4 \%$ of the total glucose produced in sheep (Heitmann and Bergman, 1981). Other studies also report that postruminal Glu infusion increases plasma glucose concentration in sheep (Elsabagh et al., 2018) and lactating dairy cows (Ansia et al., 2017). Glutamine and Glu play similar physiological roles in the gut tissues (Heitmann and Bergman, 1981), and effects of postruminal Gln infusion were evaluated for transition dairy cows (Doepel et al., 2006). However, the effects of supplementing Glu in the diet of dairy cows during the calving transition period have not been studied.

We hypothesized that feeding rumen-protected Glu during the calving transition period would increase apparent total-tract digestibility (ATTD), decrease inflammation, and increase milk production. The objective of our study was to evaluate the effects of rumen-protected Glu supplementation during the calving transition period on ATTD, inflammation, blood metabolites, and productivity of dairy cows.

\section{MATERIALS AND METHODS}

All experimental procedures were pre-approved by the University of Alberta Animal Care and Use Committee for Livestock (AUP\#3193) and conducted according to the guidelines of the Canadian Council on Animal Care (2009).

\section{Animals, Diets, and Experimental Design}

Fifty-two multiparous Holstein dairy cows (Table 1) were blocked by parity, expected calving date, and BCS, and randomly assigned to 1 of the 2 treatments.
Cows were fed diets with rumen-protected monosodium Glu monohydrate prototype supplement (RP-Glu; Ajinomoto Co. Inc.; $\mathrm{n}=26$ ) as a part of TMR or without RP-Glu (CON; $\mathrm{n}=26$ ) from d $21 \pm 3$ before the expected calving date until d $21 \pm 3$ after calving. The RP-Glu contained $50.2 \%$ of hydrogenated soy oil to coat Glu to protect from ruminal digestion, $38.4 \%$ of Glu, $6 \%$ of sodium, and $5.4 \%$ of water on a $55^{\circ} \mathrm{C}$ DM base. The in situ ruminal degradability of Glu was $19 \%$, and in vitro intestinal digestibility, determined in a 3-step in vitro procedure (Miyazawa et al., 2014), was $23 \%$ (of the total Glu). The RP-Glu was expected to provide $8.8 \%$ of intestinally available Glu $(38.4 \%$ $\times 23 \%$ ). Prepartum and postpartum diets were formulated using AMTS Cattle Professional version 4.15.0 (Agricultural Modeling and Training Systems LLC) to meet or exceed nutrient requirements for a $680-\mathrm{kg}$ of BW cow through the peripartum period and for producing $31 \mathrm{~kg} / \mathrm{d}$ of milk with $4 \%$ milk fat and $3.3 \%$ milk $\mathrm{CP}$ for the postpartum period (Table 2). Cows were fed RP-Glu at $4 \%$ of dietary DM during the prepartum period and at $3 \%$ of dietary DM during the postpartum period. We intended to supply RP-Glu at $0.48 \mathrm{~kg} / \mathrm{d}$ on a DM basis assuming DMI was 12 and $16 \mathrm{~kg} / \mathrm{d}$ for prepartum and postpartum periods, respectively, to provide $42 \mathrm{~g} / \mathrm{d}$ of intestinally available Glu, which was evaluated in a previous study $(0.4 \mathrm{mmol} / \mathrm{kg}$ of $\mathrm{BW}$; Ansia et al., 2017). In the literature, Glu absorption in the small intestine ranges from 191 to $262 \mathrm{~g} / \mathrm{d}$ in lactating dairy cows (Stern et al., 1985; Waltz et al., 1989; Berthiaume et al., 2001). As such, the $42 \mathrm{~g} / \mathrm{d}$ of intestinally available Glu is expected to increase Glu absorption by approximately $20 \%$. The hydrogenated soy oil and sodium bicarbonate were added to the CON diet to match the hydrogenated soy oil and available sodium content of RP-Glu. Anionic salts were added to both prepartum diets, but we could not add enough to make the DCAD below zero due to palatability-related concerns. Cows were housed in individual tiestalls at the Dairy Research and Technology Centre at the University of Alberta (Edmonton, AB, Canada) and had free access to water. All cows were individually fed experimental diets as TMR in mangers once daily at $0800 \mathrm{~h}$ to allow for 5 to $10 \%$ refusals (as-fed basis) based on actual feed intake of the previous day. Cows were allowed to exercise in a paddock for $3 \mathrm{~h} 3$ times a week. After calving, cows were milked twice daily at $0600 \mathrm{~h}$ and $1700 \mathrm{~h}$.

\section{Data and Sample Collection}

Individual DMI was recorded daily throughout the experimental period. Forage and concentrate samples were collected once weekly. The DM concentrations of 
forage and concentrate samples were determined in a forced-air oven at $55^{\circ} \mathrm{C}$ for $48 \mathrm{~h}$. Experimental diets were adjusted with the determined DM as necessary to feed the same experimental diets on a DM basis.

Milk yield was recorded at each milking from $\mathrm{d} 1$ to 21 after calving. Milk samples were collected from 2 consecutive milkings (p.m. and a.m.) weekly. The BW and BCS were measured on $\mathrm{d}-21 \pm 3$ relative to the expected calving date, immediately after calving, and on d $21 \pm 3$ after calving. After calving, BW was measured after milking and before feeding in the morning on 2 consecutive days, and BCS was taken by 2 individuals using a 5-point scale (Wildman et al., 1982). Both BW and BCS were averaged before statistical analysis, and BW changes after calving and BCS changes before and after calving were calculated.

Blood samples were collected before feeding on $\mathrm{d}-21$ \pm 3 , and twice weekly from $\mathrm{d}-10$ before the expected calving date. The samples on $\mathrm{d}-3 \pm 2$ relative to the actual calving date were selected for analyses. After calving, blood samples were collected after morning milking but before feeding on d 4, 7, 10, and 21. Blood samples were collected via the coccygeal vein into evacuated tubes containing no anticoagulant (Fisher Scientific) for serum collection and evacuated tubes containing sodium heparin (Fisher Scientific) or $\mathrm{K}_{2}$ EDTA (Fisher Scientific) for plasma collection. Evacuated tubes without anticoagulant were kept at room temperature for at least 30 min to harvesting serum. A protease inhibitor, aprotinin $(5 \mu \mathrm{L} ; 0.01 \mathrm{mg} / \mu \mathrm{L} ; \mathrm{A} 1153-25 \mathrm{mg}$, SigmaAldrich Canada Co.), was added to $10-\mathrm{mL}$ evacuated tubes containing sodium heparin immediately after sampling, and both evacuated tubes with sodium heparin or $\mathrm{K}_{2}$ EDTA were placed on ice after sampling. All evacuated tubes were centrifuged at $3,000 \times g(20 \mathrm{~min}$,

Table 1. Parity, BCS, and BW of dairy cows at enrollment (d $-21 \pm$ 3 relative to expected calving date)

\begin{tabular}{lcc}
\hline & \multicolumn{2}{c}{ Treatment $^{1}$} \\
\cline { 2 - 3 } Variable & CON $( \pm \mathrm{SD})$ & RP-Glu $( \pm \mathrm{SD})$ \\
\hline $\mathrm{n}$ & 26 & 26 \\
Parity & $2.5 \pm 1.4$ & $2.3 \pm 1.1$ \\
BCS & $3.20 \pm 0.35$ & $3.21 \pm 0.34$ \\
BW, kg & $791 \pm 90$ & $792 \pm 79$ \\
Subset & & 10 \\
n & 9 & $1.9 \pm 1.3$ \\
Parity & $2.0 \pm 1.0$ & $3.13 \pm 0.28$ \\
BCS & $3.26 \pm 0.23$ & $791 \pm 60$ \\
BW, kg & $821 \pm 69$ &
\end{tabular}

${ }^{1} \mathrm{CON}=$ control diet, no rumen-protected monosodium glutamate (RP-Glu) supplementation; RP-Glu = diet supplemented with RPGlu.

${ }^{2} \mathrm{~A}$ subset of 19 cows was used for digestibility measurements. $\left.4^{\circ} \mathrm{C}\right)$ to harvest serum or plasma. Serum and plasma samples were stored at $-80^{\circ} \mathrm{C}$ freezer until analysis.

A subset of 20 cows with close calving dates (within a 2-mo period) was used to measure ATTD of DM, OM, $\mathrm{CP}, \mathrm{NDF}$, and starch. Fecal samples were collected from the rectum, starting on $\mathrm{d} 5 \pm 1$ and $21 \pm 3$ after calving, every $9 \mathrm{~h}$ over a 72 -h period to account for diurnal variation, composited for each cow, and stored at $-20^{\circ} \mathrm{C}$. Fecal samples were thawed at room temperature and dried in a forced-air oven at $55^{\circ} \mathrm{C}$ for $72 \mathrm{~h}$.

\section{Sample Analyses}

Dried feed and fecal samples were ground with a Wiley mill (Thomas Scientific) with a 1-mm screen and analyzed by Cumberland Valley Analytical Services (Waynesboro, PA) for DM (AOAC International, 2002; method 930.15), OM (AOAC International, 2002; method 942.05), CP (AOAC International, 2000; method 990.03), NDF (Van Soest et al., 1991), ether extract (AOAC International, 2006; method 2003.05), and starch (Hall, 2009). Indigestible NDF (iNDF) was determined after $240 \mathrm{~h}$ of in vitro digestion (Goering and Van Soest., 1970), which was used as an internal marker to predict fecal output to calculate ATTD (Cochran et al., 1986). The ATTD was calculated with the following equation:

$$
\begin{gathered}
\text { ATTD }(\% \text { of nutrient intake })= \\
100-\{100 \times[\text { dietary iNDF content }(\% \mathrm{DM}) /
\end{gathered}
$$

fecal iNDF content $(\% \mathrm{DM})] \times[$ fecal nutrient content

$$
(\% \mathrm{DM}) / \text { dietary nutrient content }(\% \mathrm{DM})]\} \text {. }
$$

Milk samples were analyzed individually for concentrations of milk fat, milk CP, lactose, MUN, SCC, and BHB by mid-infrared spectroscopy (ISO-IDF, 2013; ISO 9622|IDF 141; Foss System MilkoScan 7RM, Foss North America) at Lactanet Canada Central Milk Testing Laboratory (Edmonton, AB, Canada). The ECM was calculated as $(0.3246 \times$ milk yield, $\mathrm{kg})+(12.86$ $\times$ milk fat yield, $\mathrm{kg})+(7.04 \times$ milk $\mathrm{CP}$ yield, $\mathrm{kg})$, according to the equation described by Bernard (1997). Feed efficiency was calculated as ECM divided by DMI.

Serum samples were analyzed using commercial kits for concentrations of serum amyloid A (Tridelta Development Limited) and haptoglobin (Tridelta Development Limited). In addition, serum samples were analyzed for concentrations of FFA (Eiken Chemical Co. Ltd.), BHB (FUJIFILM Wako Pure Chemical Corporation), total bilirubin (Alfresa Pharma Corporation), and urea N (Denka Company Limited) using 7180 Clinical Analyzer (Hitachi High-Technologies Corporation). 
Table 2. Ingredients and nutrient composition of experimental diets ${ }^{1}$

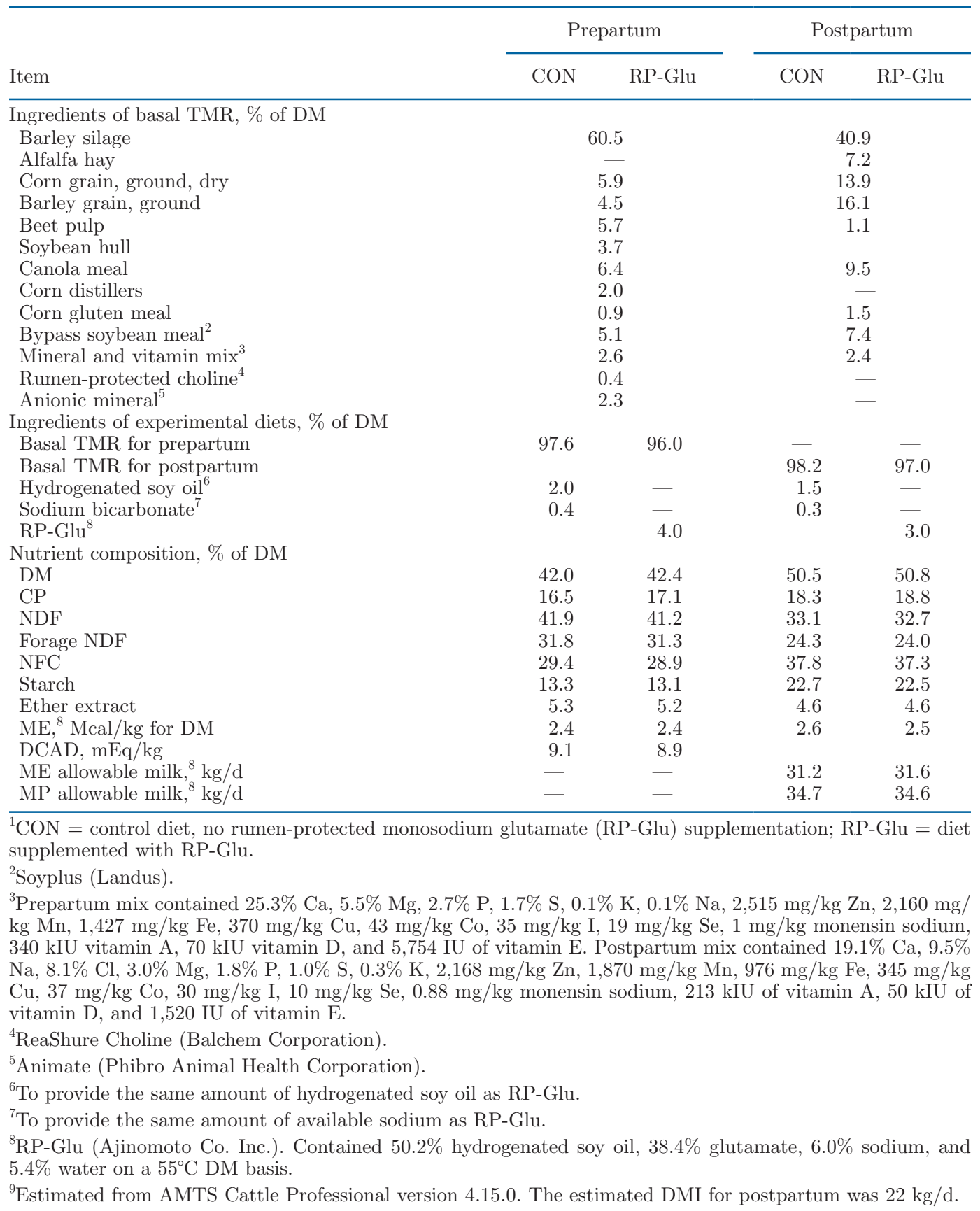

Plasma samples treated with sodium heparin and aprotinin were analyzed for LPS binding protein (LBP) concentration using a commercial kit (Hycult Biotech), and for concentrations of IGF-1 and glucagon-like peptide-2 (GLP-2) with a time-resolved fluoroimmunoassay technique using a 2030 Multilabel Reader ARVO X4 (PerkinElmer Inc.) as described by Engelking et al. (2020). Plasma samples treated with $\mathrm{K}_{2}$ EDTA were analyzed for plasma glucose concentration using a commercial kit (FUJIFILM Wako Diagnostics
USA Corporation), and for concentrations of AA and 3-methylhistidine using Amino Acid Analyzer L-8900 (Hitachi High-Technologies Corporation) as described by Zang et al. (2019).

\section{Statistical Analysis}

All data were analyzed using the Fit Model procedure of JMP Pro 14.3 (SAS Institute Inc.). Data were analyzed separately for $\mathrm{d}-3 \pm 2$ relative to calving and 
for the postpartum period using the following models [1] and [2], respectively:

$$
\begin{gathered}
Y_{i k l}=\mu+T_{i}+B_{k}+C(B)_{l(k)}+e_{i k l l}, \\
Y_{i j k l}=\mu+T_{i}+P_{j}+T P_{i j}+B_{k}+C(B)_{l(k)}+e_{i j k l},[2]
\end{gathered}
$$

where $Y_{i k l}$ or $Y_{i j k l}=$ observations for dependent variables; $\mu=$ overall mean, $T_{i}=$ fixed effect of treatment (CON or RP-Glu); $P_{j}=$ fixed effect of time period (day or week) as a repeated measure; $T P_{i j}=$ fixed effect of treatment and time period interaction; $B_{k}=$ fixed effect of block; $C(B)_{l(k)}=$ random effect of cow nested in block; and $e_{i k l}$ or $e_{i j k l}=$ residuals. As the pre-trial FFA concentration $(\mathrm{d}-21 \pm 3)$ was different between treatments, it was used as a covariate for analysis of all FFA data. For repeated measures, a covariance structure with the smallest Akaike's information criterion was selected (Littell et al., 1996). The $t$-test was used when interactions between treatment by time were detected. Significance was declared at $P \leq 0.05$, and tendency was found at $0.05<P \leq 0.10$.

\section{RESULTS}

Postpartum data of 2 cows were not used for statistical analyses; one cow fed the RP-Glu was killed after milk fever, and the other cow fed the CON diet, to be used for ATTD measurements, had a severe teat injury. Following parturition, 20 cases of postpartum health disorders in 13 cows were treated $(3$ milk fever, 4 subclinical ketosis, 2 displaced abomasum, 2 mastitis, and 1 metritis for the RP-Glu treatment; 2 milk fever, 1 subclinical ketosis, 2 retain placenta, 1 edema, 1 pneumonia, and 1 teat injury for $\mathrm{CON}$ ). For cows treated with antibiotics, anti-inflammatory drugs, or propylene glycol, data collected immediately after treatment were excluded from statistical analyses.

\section{DMI, BW, BCS, and Milk Production}

No treatment effects were observed between cows fed the RP-Glu and CON in DMI (14.3 vs. $13.6 \mathrm{~kg} / \mathrm{d} ; P$ $=0.23)$ and BCS change $(-0.16$ vs. $-0.09 ; P=0.27)$ during the prepartum period (Table 3). However, an interaction between treatment and day was detected for DMI in the postpartum period $(P=0.03)$, and cows fed the RP-Glu had a greater DMI on d 1 after calving $(15.7$ vs. $13.7 \mathrm{~kg} / \mathrm{d} ; P=0.03$; Figure 1$)$. There were no differences between the 2 groups in postpartum changes in BW and BCS, yields of milk, and milk fat; however, cows fed the RP-Glu had lower lactose yield (1.96 vs. $2.16 \mathrm{~kg} / \mathrm{d} ; P=0.05)$, and tendencies for lower yields of milk CP (1.46 vs. $1.59 \mathrm{~kg} / \mathrm{d} ; P=0.06)$, milk total solids (5.77 vs. $6.26 \mathrm{~kg} / \mathrm{d} ; P=0.06)$, and $\mathrm{ECM}(48.2$ vs. $51.9 \mathrm{~kg} / \mathrm{d} ; P=0.08)$.

\section{Circulating Metabolites, Hormone, Inflammatory Markers, and AA}

No differences were observed between the 2 treatments in concentrations of circulating metabolites, plasma IGF-1, and serum and plasma inflammatory markers on $\mathrm{d}-3$ relative to calving date (Table 4). During the postpartum period, no treatment effects were observed in concentrations of serum BHB and plasma glucose between RP-Glu and CON diets (Table 5). Interactions between treatment and day during postpartum period were observed in concentrations of serum FFA $(P<0.01)$, serum total bilirubin $(P<$ $0.01)$, plasma 3 -methylhistidine $(P=0.03)$, and plasma IGF-1 $(P=0.02)$. On d 4 after calving, feeding RP-Glu diet compared with $\mathrm{CON}$ decreased concentrations of serum FFA (670 vs. $981 \mu \mathrm{Eq} / \mathrm{L} ; P<0.01$; Figure 2 A), total bilirubin $(0.22$ vs. $0.34 \mathrm{mg} / \mathrm{dL} ; P<0.01$; Figure 2B), and plasma 3 -methylhistidine (1.28 vs. $1.50 \mu \mathrm{mol} /$ $\mathrm{dL} ; P=0.03$; Figure 2C), and increased plasma IGF-1 concentrations ( 44.2 vs. $30.1 \mathrm{ng} / \mathrm{mL} ; P<0.01$; Figure $2 \mathrm{D})$. There were time effects for concentrations of serum amyloid A $(P<0.01)$, haptoglobin $(P<0.01)$, and plasma LBP $(P<0.01)$ as inflammatory markers; however, no treatment effects or treatment and time interactions were detected during the postpartum period. Cows fed RP-Glu compared with CON had lower Gln (306 vs. $344 \mu M ; P=0.05$; Table 6$)$ on $\mathrm{d}-3 \pm$ 2 relative to calving. Lower plasma His (47.3 vs. 52.9 $\mu M ; P=0.04$; Table 7 ) and Thr (86.1 vs. $96.6 \mu M ; P=$ $0.05)$ concentrations were observed for cows fed RP-Glu during the postpartum period. There were interactions between treatment and day in plasma concentrations of Trp $(P=0.02)$, Asn $(P=0.02)$, Asp $(P=0.01)$, Gln $(P<0.01)$, Glu $(P=0.02)$, and Tyr $(P=0.02)$ during the postpartum period. Lower plasma concentrations of Trp (29.6 vs. $33.7 \mu M ; P=0.04$; Figure $3 \mathrm{~A})$ on $\mathrm{d}$ 21 after calving and Asn on d 10 (47.6 vs. $55.0 \mu M$; $P$ $=0.03$; Figure $3 \mathrm{~B}$ ) and $\mathrm{d} 21$ (49.0 vs. $55.7 \mu M ; P=$ 0.04 ) after calving were observed for cows fed RP-Glu compared with CON. Cows fed RP-Glu had greater plasma concentrations of Asp (4.1 vs. $3.3 \mu M ; P<0.01$; Figure $3 \mathrm{C}$ ), Gln (357 vs. $315 \mu M ; P=0.02$; Figure 3D), Glu (46.0 vs. $38.9 \mu M ; P<0.01$; Figure $3 \mathrm{E}$ ), and Tyr (43.8 vs. $37.3 \mu M ; P=0.05$; Figure $3 \mathrm{~F}$ ) compared with CON only on $\mathrm{d} 4$ after calving.

\section{Apparent Total-Tract Digestibility}

Treatment by time interactions $(P<0.05$; Table 8$)$ were observed for ATTD of DM, OM, CP, and NDF. 
Cows fed RP-Glu had greater ATTD of DM (70.6 vs. $69.1 \% ; P=0.05)$, and $\mathrm{CP}(75.1$ vs. $72.6 \% ; P=0.03)$ on $\mathrm{d} 5 \pm 1$ after calving, but lower ATTD of CP (73.9 vs. $74.7 \% ; P=0.01)$ on $\mathrm{d} 21 \pm 3$ compared with CON.

\section{DISCUSSION}

In the present study, cows fed the RP-Glu diet had greater plasma Glu concentration only on d 4 after calving, and positive responses to the RP-Glu diet were observed within $5 \mathrm{~d}$ after calving (e.g., greater DMI on d 1 after calving, greater plasma IGF-1 concentration on d 4 after calving, greater ATTD on d $5 \pm 1$ after calving, and lower concentrations of serum FFA, serum bilirubin, and plasma 3-methylhistidine on d 4 after calving). However, once the RP-Glu supplementation did not affect plasma Glu concentration (i.e., after d 4 ), we did not observe any positive animal responses to the RP-Glu treatment. These results indicated that animal responses to RP-Glu may be related to whether additional Glu supply from diet increases its plasma concentration.

Glutamate is considered as a NEAA, and NRC (2001) does not establish its dietary requirement for dairy cows. However, previous studies reported that postruminal Glu infusion increased plasma Glu concentration in 48-h fasted sheep (Elsabagh et al., 2018) and feed restricted mid-lactation cows (Ansia et al., 2017). Similarly, we observed that cows fed the RP-Glu diet had greater plasma Glu concentration only right after calving. These findings suggest that Glu supply from the gut lumen can affect its plasma concentration when intake is low. Although Glu can be synthesized from other AA or metabolites (Burrin and Stoll., 2009; Wu, 2013), RP-Glu supplementation increased plasma Glu concentration and resulted in several positive animal responses at the same time. This indicates that Glu synthesis can be insufficient under certain conditions,

Table 3. The effects of supplementation of rumen-protected monosodium glutamate (RP-Glu) on DMI and production performance $^{1}$

\begin{tabular}{|c|c|c|c|c|c|c|}
\hline \multirow[b]{2}{*}{ Variable } & \multirow[b]{2}{*}{$\mathrm{CON}$} & \multirow[b]{2}{*}{ RP-Glu } & \multirow[b]{2}{*}{$\mathrm{SE}$} & \multicolumn{3}{|c|}{$P$-value } \\
\hline & & & & Trt & Time & Trt $\times$ time \\
\hline \multicolumn{7}{|l|}{ Prepartum } \\
\hline DMI, kg/d & 13.6 & 14.3 & 0.4 & 0.23 & 0.09 & 0.47 \\
\hline BCS change, $/ 21 \mathrm{~d}$ & -0.09 & -0.16 & 0.05 & 0.27 & - & - \\
\hline \multicolumn{7}{|l|}{ Postpartum } \\
\hline DMI, ${ }^{2} \mathrm{~kg} / \mathrm{d}$ & 19.5 & 19.7 & 0.6 & 0.80 & $<0.01$ & 0.03 \\
\hline BW change, kg/d & -2.34 & -2.95 & 0.26 & 0.12 & - & - \\
\hline BCS change, $/ 21 \mathrm{~d}$ & -0.43 & -0.32 & 0.06 & 0.18 & - & - \\
\hline \multicolumn{7}{|l|}{ Yield, $\mathrm{kg} / \mathrm{d}$} \\
\hline Milk & 42.1 & 39.4 & 1.2 & 0.12 & $<0.01$ & 0.26 \\
\hline Fat & 2.05 & 1.92 & 0.05 & 0.28 & 0.53 & 0.11 \\
\hline $\mathrm{CP}$ & 1.59 & 1.46 & 0.05 & 0.06 & 0.04 & 0.54 \\
\hline Lactose & 2.16 & 1.96 & 0.07 & 0.05 & $<0.01$ & 0.24 \\
\hline TS & 6.26 & 5.77 & 0.17 & 0.06 & 0.05 & 0.64 \\
\hline ECM & 51.9 & 48.2 & 1.4 & 0.08 & 0.03 & 0.24 \\
\hline ECM/DMI & 2.62 & 2.37 & 0.09 & 0.08 & $<0.01$ & 0.04 \\
\hline Wk 1 & 3.01 & 2.50 & 0.17 & $<0.01$ & - & - \\
\hline Wk 2 & 2.59 & 2.45 & 0.17 & 0.38 & - & - \\
\hline Wk 3 & 2.28 & 2.18 & 0.17 & 0.54 & - & - \\
\hline \multicolumn{7}{|l|}{ Milk composition } \\
\hline Fat, $\%$ & 4.26 & 4.34 & 0.19 & 0.76 & $<0.01$ & 0.03 \\
\hline Wk 1 & 4.90 & 4.60 & 0.35 & 0.41 & - & - \\
\hline Wk 2 & 4.26 & 4.32 & 0.33 & 0.85 & - & - \\
\hline Wk 3 & 3.67 & 4.15 & 0.34 & 0.16 & - & - \\
\hline CP, \% & 3.29 & 3.32 & 0.04 & 0.65 & $<0.01$ & 0.75 \\
\hline Lactose, \% & 4.45 & 4.47 & 0.15 & 0.55 & $<0.01$ & 0.24 \\
\hline $\mathrm{TS}, \%$ & 13.0 & 13.1 & 0.2 & 0.68 & $<0.01$ & 0.04 \\
\hline Wk 1 & 14.0 & 13.8 & 0.4 & 0.48 & - & - \\
\hline Wk 2 & 12.9 & 13.0 & 0.4 & 0.85 & - & - \\
\hline Wk 3 & 12.1 & 12.6 & 0.4 & 0.15 & - & - \\
\hline MUN, mg/dL & 15.3 & 15.2 & 0.6 & 0.98 & 0.24 & 0.41 \\
\hline $\mathrm{SCC}, 10^{3}$ cells $/ \mathrm{mL}$ & 212 & 139 & 80 & 0.53 & 0.43 & 0.03 \\
\hline Wk 1 & 378 & 87 & 160 & 0.07 & - & - \\
\hline Wk 2 & 171 & 57 & 151 & 0.45 & - & - \\
\hline Wk 3 & 87 & 275 & 153 & 0.22 & - & - \\
\hline $\mathrm{BHB}, \mathrm{mmol} / \mathrm{L}$ & 0.12 & 0.12 & 0.01 & 0.67 & 0.48 & 0.61 \\
\hline
\end{tabular}

${ }^{1} \mathrm{CON}=$ control diet, no RP-Glu supplementation; RP-Glu = diet supplemented with RP-Glu.

${ }^{2}$ Because the treatment $($ Trt $) \times$ time interaction is significant, daily DMI data are shown in Figure 1 . 
Table 4. The effects of supplementation with rumen-protected monosodium glutamate (RP-Glu) on circulating concentrations of metabolites, hormones, and inflammatory markers on $\mathrm{d}-3$ relative to calving ${ }^{1}$

\begin{tabular}{|c|c|c|c|c|}
\hline Variable & $\mathrm{CON}$ & RP-Glu & $\mathrm{SE}$ & $P$-value \\
\hline \multicolumn{5}{|l|}{ Metabolites } \\
\hline \multicolumn{5}{|l|}{ Serum } \\
\hline Free fatty acids, $\mu \mathrm{Eq} / \mathrm{L}$ & 375 & 335 & 36 & 0.44 \\
\hline $\mathrm{BHB}, \mu \mathrm{mol} / \mathrm{L}$ & 329 & 356 & 27 & 0.50 \\
\hline Total bilirubin, mg/dL & 0.15 & 0.13 & 0.01 & 0.24 \\
\hline Urea $\mathrm{N}, \mathrm{mg} / \mathrm{dL}$ & 16.9 & 17.4 & 0.5 & 0.53 \\
\hline \multicolumn{5}{|l|}{ Plasma } \\
\hline Glucose, mg/dL & 71.4 & 70.3 & 0.8 & 0.38 \\
\hline 3-Methylhistidine, $\mu \mathrm{mol} / \mathrm{dL}$ & 1.33 & 1.36 & 0.10 & 0.82 \\
\hline \multicolumn{5}{|l|}{ Hormone } \\
\hline \multicolumn{5}{|l|}{ Plasma } \\
\hline IGF-1, ng/mL & 82.0 & 83.8 & 6.4 & 0.85 \\
\hline Glucagon-like peptide-2, ng/mL & 0.91 & 0.99 & 0.07 & 0.43 \\
\hline \multicolumn{5}{|l|}{ Inflammatory marker } \\
\hline \multicolumn{5}{|l|}{ Serum } \\
\hline Serum amyloid $\mathrm{A}, \mu \mathrm{g} / \mathrm{mL}$ & 35 & 57 & 22 & 0.50 \\
\hline Haptoglobin, $\mathrm{mg} / \mathrm{mL}$ & 0.10 & 0.31 & 0.10 & 0.15 \\
\hline \multicolumn{5}{|l|}{ Plasma } \\
\hline LPS binding protein, $\mathrm{ng} / \mathrm{mL}$ & 2,795 & 2,954 & 183 & 0.56 \\
\hline
\end{tabular}

${ }^{1} \mathrm{CON}=$ control diet, no RP-Glu supplementation; RP-Glu = diet supplemented with RP-Glu.

such as reduced feed intake or increased nutrient demands with the onset of lactation, and that animals can benefit from additional Glu supply from the diet.

Cows fed RP-Glu had greater ATTD of DM and CP on d $5 \pm 1$ after calving compared with CON, although Glu was coated with hydrogenated soy oil and lower in its availability. These results suggest that additional
Glu supply can enhance digestive capacity. Our findings are consistent with previous studies showing that feeding Glu to weaning piglets increased villus height (Wu et al., 2012) and absorptive capacity (Rezaei et al., 2013) of the small intestine. As Glu is a major metabolic fuel in the small intestine in swine (Reeds et al., 2000; Burrin and Stoll, 2009) and cows (El-Kadi

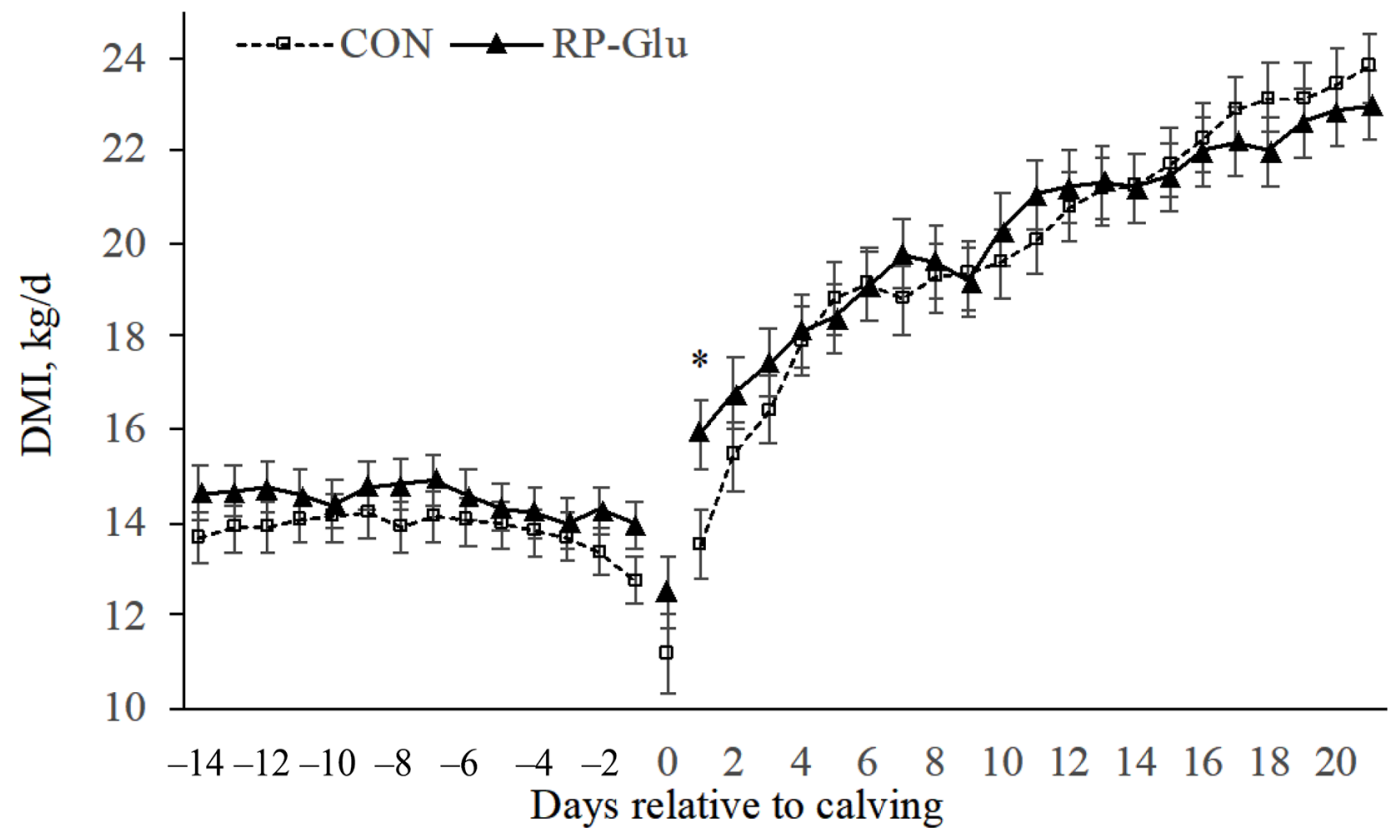

Figure 1. Daily DMI of cows supplemented with rumen-protected monosodium glutamate (RP-Glu) and without (CON) during the periparturient period. The $P$-values for treatment, day, and their interaction during the prepartum period were $0.23,0.09$, and 0.47 , respectively. The $P$-value for treatment on d 0 relative to calving was 0.27 . The $P$-values for treatment, day, and their interaction during postpartum period were $0.80,<0.01$, and 0.03 , respectively. Postpartum data were analyzed individually for each time point using $t$-test. ${ }^{*}$ Effect of RP-Glu on DMI was significant $(P<0.05)$ on d 1 after calving. Data shown are LSM \pm SE. 
et al., 2009), it is also possible that periparturient RPGlu supplementation expedited the intestinal growth, leading to greater ATTD during the first week after calving. However, the RP-Glu treatment did not affect ATTD of DM at 3 wk after calving. Dietary Glu supply may not affect the intestinal growth or digestive capacity once the critical periparturient period has passed. In fact, cows fed the RP-Glu diet had lower ATTD of CP at 3 wk after calving. The extent of nutrient digestion is determined by feed characteristics, such as processing method, as well as digestive capacity of the animal. As the total in situ and in vitro digestibility of Glu was only $42 \%$ ( $19 \%$ in the rumen and $23 \%$ postrumen) for the RP-Glu prototype, cows fed the RP-Glu would likely have lower CP digestibility if digestive capacity of the animal is similar.

The greater DMI observed for cows fed RP-Glu on d 1 after calving may be related to delayed satiety signals due to less hepatic oxidation (Allen et al., 2009). As discussed above, if the RP-Glu supplementation expedited intestinal growth, more metabolic fuels would be oxidized by the gut tissues, resulting in less oxidative fuels reaching the liver. Less hepatic oxidation can delay satiety and increase DMI (Allen et al., 2009). Another possible reason for greater DMI for cows fed the RP-Glu is hormonal control. In a previous study, duodenal Glu infusion in 48-h fasted sheep increased plasma ghrelin concentration (Elsabagh et al., 2018). As ghrelin increases feed intake (Kojima et al., 1999), the greater DMI for the RP-Glu treatment might be mediated by ghrelin. However, cows fed the RP-Glu did not have greater DMI beyond d 1 after calving, indicating that additional dietary Glu supply from the RP-Glu supplementation did not have sustained effects on hepatic oxidation, ghrelin secretion, or other unidentified mechanisms regulating feed intake.

Cows fed the RP-Glu had greater plasma IGF-1 concentration on d 4 after calving, which is likely due to greater nutritional intake (Clemmons and Underwood, 1991) from greater DMI immediately after calving for the RP-Glu treatment. Cows fed the RP-Glu also had lower plasma 3-methylhistidine concentration on $\mathrm{d} 4$ after calving, which suggests less body muscle protein mobilization (McCabe and Boerman, 2020). Greater MP supply from the higher DMI immediately after calving for cows fed RP-Glu may have contributed to less muscle catabolism (Carder and Weiss, 2017). In addition, the greater DMI likely reduced serum FFA concentration on d 4 after calving for cows fed the RPGlu, suggesting less body fat mobilization (Reece et al., 2015). The reduced body fat mobilization may subsequently contribute to enhanced liver functions, indicated by less serum total bilirubin concentration (West, 1990; Bertoni and Trevisi, 2013) on d 4 after calving for cows fed the RP-Glu. However, these responses in metabolites did not continue as the treatment effect on DMI disappeared.

Intestinal barrier dysfunction can be caused by reduced feed intake (Pearce et al., 2013; Kvidera et al., 2017), increasing gut-derived inflammation right after

Table 5. The effects of supplementation with rumen-protected monosodium glutamate (RP-Glu) on concentrations of circulating metabolites, hormones, and inflammatory markers during the postpartum period ${ }^{1,2}$

\begin{tabular}{|c|c|c|c|c|c|c|}
\hline Variable & $\mathrm{CON}$ & RP-Glu & $\mathrm{SE}$ & \multicolumn{3}{|c|}{$P$-value } \\
\hline \multicolumn{7}{|l|}{ Metabolites } \\
\hline \multicolumn{7}{|l|}{ Serum } \\
\hline Free fatty acids, ${ }^{3} \mu \mathrm{Eq} / \mathrm{L}$ & 885 & 843 & 50 & 0.58 & $<0.01$ & $<0.01$ \\
\hline $\mathrm{BHB}, \mu \mathrm{mol} / \mathrm{L}$ & 669 & 737 & 81 & 0.56 & 0.08 & 0.62 \\
\hline Total bilirubin, ${ }^{3} \mathrm{mg} / \mathrm{dL}$ & 0.27 & 0.24 & 0.02 & 0.39 & $<0.01$ & $<0.01$ \\
\hline Glucose, $\mathrm{mg} / \mathrm{dL}$ & 61.8 & 62.2 & 1.2 & 0.80 & $<0.01$ & 0.14 \\
\hline 3-Methylhistidine, ${ }^{3} \mu \mathrm{mol} / \mathrm{dL}$ & 1.09 & 0.97 & 0.06 & 0.15 & $<0.01$ & 0.03 \\
\hline \multicolumn{7}{|l|}{ Hormone } \\
\hline \multicolumn{7}{|l|}{ Plasma } \\
\hline IGF- $1,{ }^{3} \mathrm{ng} / \mathrm{mL}$ & 31.8 & 41.1 & 3.3 & 0.06 & 0.76 & 0.02 \\
\hline Glucagon-like peptide-2, ng/mL & 1.01 & 1.01 & 0.06 & 0.97 & 0.98 & 0.80 \\
\hline \multicolumn{7}{|l|}{ Inflammatory marker } \\
\hline
\end{tabular}

${ }^{1} \mathrm{CON}=$ control diet, no RP-Glu supplementation; RP-Glu = diet supplemented with RP-Glu.

${ }^{2}$ Metabolite concentrations were measured on d 4, 7, 10, and 21 after calving, and the others were measured on d 4, 7, and 10 after calving.

${ }^{3}$ Because the treatment $(\mathrm{Trt}) \times$ time interaction is significant, data for each time point are shown in Figure 2. 
Table 6. The effects of supplementation with rumen-protected monosodium glutamate (RP-Glu) on plasma AA profile $(\mu M)$ on $\mathrm{d}-3$ relative to calving ${ }^{1}$

\begin{tabular}{|c|c|c|c|c|}
\hline Variable & $\mathrm{CON}$ & RP-Glu & $\mathrm{SE}$ & $P$-value \\
\hline Arg & 65.3 & 61.0 & 0.33 & 0.38 \\
\hline His & 54.1 & 53.7 & 0.21 & 0.88 \\
\hline Ile & 115 & 103 & 7 & 0.25 \\
\hline Leu & 155 & 139 & 10 & 0.26 \\
\hline Lys & 77.5 & 68.5 & 0.46 & 0.20 \\
\hline Met & 25.7 & 23.4 & 1.5 & 0.29 \\
\hline Phe & 54.7 & 54.7 & 3.3 & 1.00 \\
\hline Thr & 90.1 & 76.8 & 5.1 & 0.09 \\
\hline Trp & 24.5 & 23.0 & 1.4 & 0.48 \\
\hline Val & 216 & 194 & 10 & 0.15 \\
\hline Ala & 206 & 206 & 10 & 0.50 \\
\hline Asn & 44.6 & 41.1 & 0.25 & 0.36 \\
\hline Asp & 3.6 & 4.1 & 0.3 & 0.22 \\
\hline Cys & $\mathrm{ND}^{2}$ & ND & - & - \\
\hline Gln & 344 & 306 & 12 & 0.05 \\
\hline Glu & 42.3 & 46.1 & 2.2 & 0.25 \\
\hline Gly & 511 & 515 & 33 & 0.93 \\
\hline Pro & 88.9 & 81.2 & 3.9 & 0.19 \\
\hline Ser & 115 & 116 & 8 & 0.89 \\
\hline Tyr & 39.4 & 38.3 & 2.3 & 0.76 \\
\hline
\end{tabular}

${ }^{1} \mathrm{CON}=$ control diet, no RP-Glu supplementation; RP-Glu $=\operatorname{diet}$ supplemented with RP-Glu.

${ }^{2} \mathrm{ND}=$ not detected.

calving. We hypothesized that feeding the RP-Glu would reduce gut-derived inflammation because Glu contributes to the intestinal mucosal barrier function by enhancing cell growth, maintaining membrane integrity (Jiao et al., 2015), and increasing antioxidant function (Yin et al., 2015) in swine. However, no treatment effects were observed for concentrations of circulating acute phase proteins such as serum amyloid A, serum haptoglobin, and plasma LBP, although they peaked on d 4 after calving in both groups, indicating that the RP-Glu supplementation did not decrease systemic inflammation. Plaizier et al. (2018) reported that SARA increased concentrations of circulating acute phase proteins in some studies, but not in others. In the current study, we did not observe treatment effects on these inflammation markers. Serum amyloid A and haptoglobin are not specific markers for gutderived inflammation, but are systemic inflammation markers that also respond to infections such as mastitis or metritis (Ceciliani et al., 2012). However, we did not see treatment effects on LBP concentrations, either. In the bloodstream, LBP binds with LPS to clear it from the systemic circulation (Ceciliani et al., 2012), and circulating LBP concentration indicates the extent of the intestinal damage and barrier function (Kvidera et al., 2017). As such, our findings suggested that gutderived inflammation was not mitigated by additional dietary Glu supply.

As Glu is a primary energy source in the small intestine (Reeds et al., 2000) and a glucogenic AA (Heitmann and Bergman, 1981), we also expected that feeding RPGlu would spare glucose utilization, reduce serum BHB concentration, and increase milk production. However, there were no differences in concentrations of plasma
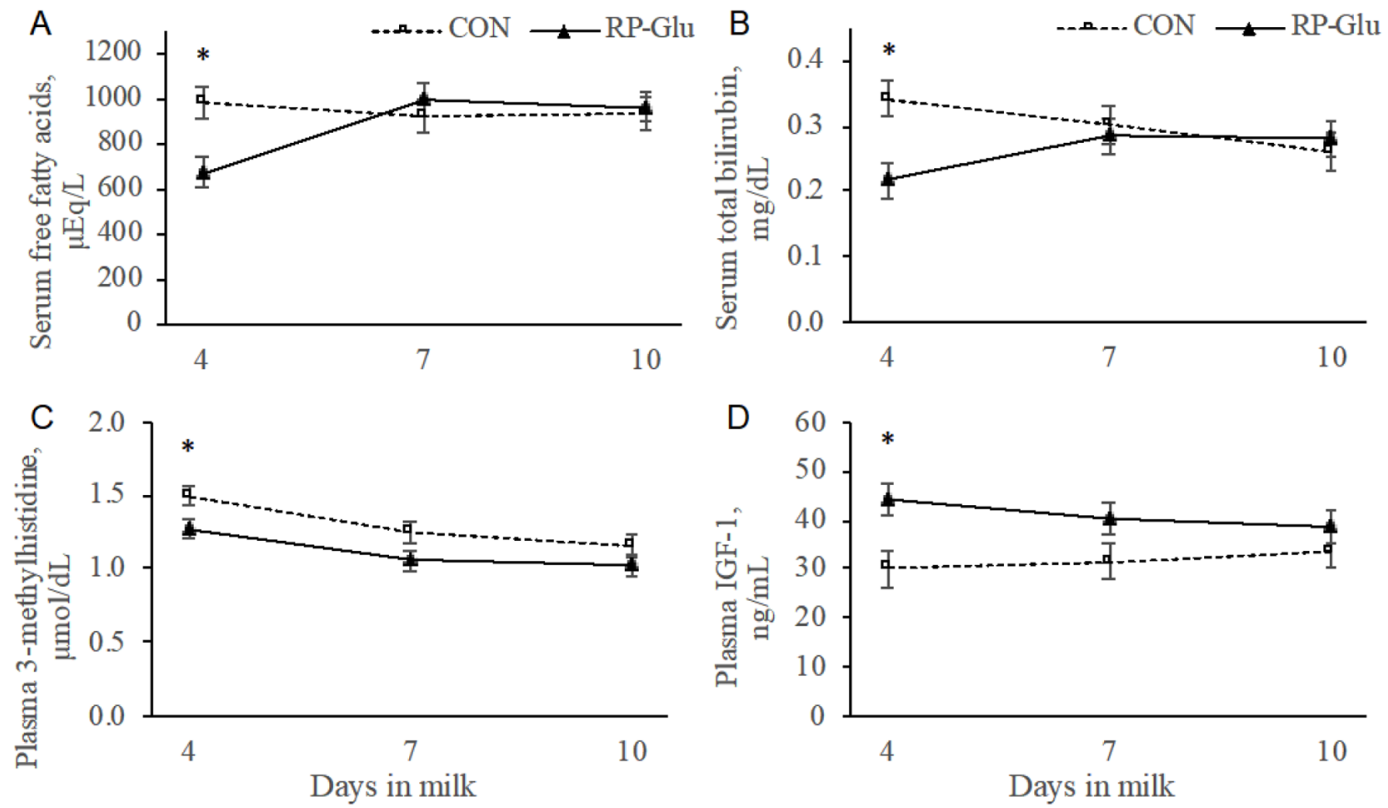

Figure 2. The effects of supplementation of rumen-protected monosodium glutamate (RP-Glu) on concentrations of serum free fatty acids (A), serum total bilirubin (B), plasma 3-methylhistidine (C), and plasma IGF-1 (D). Because interactions between treatment and day were significant, data were analyzed individually for each time point using $t$-test $\left({ }^{*} P<0.05\right)$. Data shown are LSM $\pm \mathrm{SE}$. 
glucose and serum BHB, and milk yield between the RP-Glu treatment and CON. In fact, cows fed the RPGlu had lower lactose yield and tended to have lower milk protein, total solids, and ECM yields. Cows fed the RP-Glu had lower plasma concentrations of His and Thr, and this may partly account for the tendency for lower milk component yields for the RP-Glu treatment. A positive correlation was observed between milk protein yield and plasma His concentration $(\mathrm{r}=0.34 ; P$ $=0.02$ ) in the present study. Previous studies reported that His can be a limiting AA when cows are fed a MPdeficient diet (Lee et al., 2012; Giallongo et al., 2015), and feeding His-deficient diets decreased milk and milk protein yield (Giallongo et al., 2016, 2017). Therefore, His may limit milk production for cows fed the RP-Glu in the current study; however, the exact reason for the lower plasma His concentration for the RP-Glu cows after calving is unknown.

The lower plasma Thr concentration may also account for the lower milk component yields for cows fed the RP-Glu diet. In the current study, plasma Thr concentration was positively correlated with milk protein yield $(\mathrm{r}=0.58 ; P<0.01)$ and ECM yield $(\mathrm{r}$ $=0.42 ; P=0.01)$. Threonine is the primary $\mathrm{AA}$ in mucins, the main structural component of mucus in the small intestine (Kim and Khan, 2013). As the mucus thickness in the small intestine was increased by Glu perfusion in rats (Akiba et al., 2009) or by adding Glu to the diet in weaned piglets ( $\mathrm{Wu}$ et al., 2012), it is possible that cows fed the RP-Glu had greater mucin secretion, which increases Thr utilization (Van Der Schoor et al., 2002). If more Thr is consumed in the gut tissues, cows fed the RP-Glu would have decreased plasma concentration of Thr, decreasing its availability for milk protein production.

In the current study, feeding the RP-Glu did not increase milk production nor decrease inflammation, and all the positive responses to the RP-Glu treatment, such as greater ATTD and DMI, were observed transiently only between d 1 and 5 after calving. Overall, Glu may not be required in the diet of dairy cows, but our findings suggest that cows may not be able to synthesize sufficient Glu in the body immediately after calving, and that Glu supplementation during the periparturient period can contribute to greater ATTD and DMI, and to less mobilization of body fat and muscle protein immediately after calving. Dairy NRC (2001) does not establish NEAA requirements including Glu, but further research is warranted to evaluate de novo synthesis and whole body utilization of NEAA under specific conditions when animals experience metabolic stresses.

\section{CONCLUSIONS}

Feeding the RP-Glu to dairy cows from the close-up period through the fresh period increased ATTD of DM and $\mathrm{CP}$ on $\mathrm{d} 5 \pm 1$ after calving. In addition, RP-Glu

Table 7. The effects of supplementation with rumen-protected monosodium glutamate (RP-Glu) on plasma AA profile $(\mu M)$ on $\mathrm{d} 4,7,10$, and 21 after calving $^{1}$

\begin{tabular}{|c|c|c|c|c|c|c|}
\hline \multirow[b]{2}{*}{ Variable } & \multirow[b]{2}{*}{$\mathrm{CON}$} & \multirow[b]{2}{*}{ RP-Glu } & \multirow[b]{2}{*}{$\mathrm{SE}$} & \multicolumn{3}{|c|}{$P$-value } \\
\hline & & & & Trt & Time & Trt $\times$ time \\
\hline Arg & 64.9 & 63.6 & 1.8 & 0.63 & $<0.01$ & 0.32 \\
\hline His & 52.9 & 47.3 & 1.8 & 0.04 & $<0.01$ & 0.24 \\
\hline Ile & 119 & 121 & 6 & 0.87 & $<0.01$ & 0.26 \\
\hline Leu & 166 & 165 & 6 & 0.91 & $<0.01$ & 0.30 \\
\hline Lys & 77.4 & 76.1 & 2.1 & 0.68 & $<0.01$ & 0.78 \\
\hline Met & 25.3 & 24.8 & 0.6 & 0.60 & $<0.01$ & 0.38 \\
\hline Phe & 55.5 & 55.7 & 1.1 & 0.91 & 0.06 & 0.75 \\
\hline Thr & 96.6 & 86.1 & 3.5 & 0.05 & $<0.01$ & 0.24 \\
\hline $\operatorname{Trp}^{3}$ & 28.1 & 26.0 & 1.0 & 0.23 & $<0.01$ & 0.02 \\
\hline Val & 231 & 232 & 8 & 0.93 & $<0.01$ & 0.18 \\
\hline Ala & 221 & 213 & 7 & 0.45 & $<0.01$ & 0.18 \\
\hline $\mathrm{Asn}^{3}$ & 48.8 & 45.2 & 1.5 & 0.12 & $<0.01$ & 0.02 \\
\hline $\mathrm{Asp}^{3}$ & 3.4 & 3.6 & 0.2 & 0.45 & $<0.01$ & 0.01 \\
\hline Cys & $\mathrm{ND}^{2}$ & ND & - & - & - & - \\
\hline $\mathrm{Gln}^{3}$ & 333 & 332 & 9 & 0.94 & 0.03 & $<0.01$ \\
\hline $\mathrm{Glu}^{3}$ & 40.5 & 43.4 & 1.3 & 0.14 & 0.04 & 0.02 \\
\hline Gly & 605 & 580 & 21 & 0.41 & $<0.01$ & 0.86 \\
\hline Pro & 105 & 102 & 4 & 0.60 & $<0.01$ & 0.25 \\
\hline Ser & 120 & 115 & 4 & 0.45 & 0.23 & 0.07 \\
\hline $\mathrm{Tyr}^{3}$ & 41.7 & 41.9 & 1.7 & 0.93 & $<0.01$ & 0.02 \\
\hline
\end{tabular}



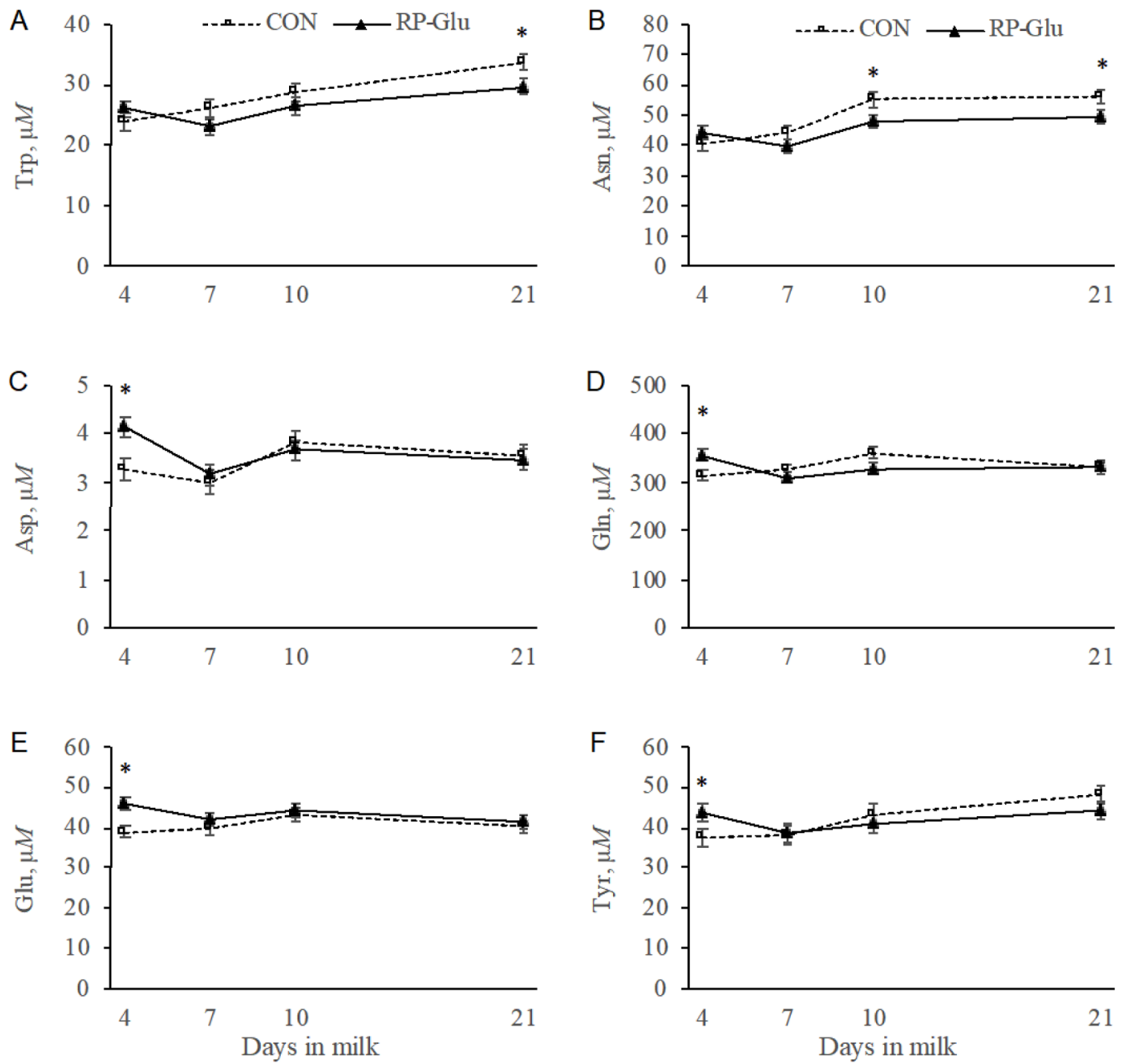

Figure 3. The effects of supplementation of rumen-protected monosodium glutamate (RP-Glu) on plasma concentrations of Trp (A), Asn (B), Asp (C), Gln (D), Glu (E), and Tyr (F). Because interactions between treatment and day were significant, data were analyzed individually for each time point using $t$-test $(* P<0.05)$. Data shown are LSM \pm SE.

Table 8. The effects of supplementation of rumen-protected monosodium glutamate (RP-Glu) on apparent total-tract digestibility (\%) of DM, OM, CP, NDF, and starch on d $5 \pm 1$ and $21 \pm 3$ after calving ${ }^{1}$

\begin{tabular}{|c|c|c|c|c|c|c|}
\hline \multirow[b]{2}{*}{ Variable } & \multirow[b]{2}{*}{$\mathrm{CON}$} & \multirow[b]{2}{*}{ RP-Glu } & \multirow[b]{2}{*}{ SE } & \multicolumn{3}{|c|}{$P$-value } \\
\hline & & & & Treatment (Trt) & Time & Trt $\times$ time \\
\hline DM & 70.1 & 70.3 & 0.41 & 0.73 & 0.11 & $<0.01$ \\
\hline d $5 \pm 1$ & 69.1 & 70.6 & 0.70 & 0.05 & - & - \\
\hline $\mathrm{d} 21 \pm 3$ & 71.0 & 70.0 & 0.70 & 0.14 & - & - \\
\hline $\mathrm{OM}$ & 71.5 & 71.6 & 0.38 & 0.85 & 0.12 & $<0.01$ \\
\hline d $5 \pm 1$ & 70.6 & 71.9 & 0.68 & 0.06 & - & - \\
\hline $\mathrm{d} 21 \pm 3$ & 72.5 & 71.4 & 0.68 & 0.12 & - & - \\
\hline $\mathrm{CP}$ & 73.7 & 74.5 & 0.52 & 0.27 & 0.46 & $<0.01$ \\
\hline d $5 \pm 1$ & 72.6 & 75.1 & 0.65 & 0.03 & - & - \\
\hline d $21 \pm 3$ & 74.7 & 73.9 & 0.65 & 0.01 & - & - \\
\hline NDF & 47.1 & 47.1 & 0.58 & 0.97 & 0.64 & 0.02 \\
\hline d $5 \pm 1$ & 45.8 & 48.0 & 1.18 & 0.08 & - & - \\
\hline $\mathrm{d} 21 \pm 3$ & 48.4 & 46.2 & 1.18 & 0.07 & - & - \\
\hline Starch & 99.5 & 99.5 & 0.11 & 0.84 & 0.05 & 0.12 \\
\hline
\end{tabular}

${ }^{1} \mathrm{CON}=$ control diet, no RP-Glu supplementation; RP-Glu = diet supplemented with RP-Glu. 
increased DMI on d 1 after calving, which is associated with greater plasma IGF-1 concentration, lower concentrations of serum FFA, serum total bilirubin, and plasma 3-methylhistidine on d 4 after calving. However, these positive responses were observed only between $d$ 1 and 5 after calving and did not continue beyond that. In addition, RP-Glu did not decrease inflammation nor increase milk production, but decreased lactose yield. Increasing dietary Glu supply during the calving transition period may not increase milk production, but its physiological roles immediately after calving should be considered in future research.

\section{ACKNOWLEDGMENTS}

The authors thank Ajinomoto Co. Inc. (Tokyo, Japan) for financial support and supplying the RP-Glu prototype product. The authors have not stated any other conflicts of interest.

\section{REFERENCES}

Akiba, Y., C. Watanabe, M. Mizumori, and J. D. Kaunitz. 2009. Luminal L-glutamate enhances duodenal mucosal defense mechanisms via multiple glutamate receptors in rats. Am. J. Physiol. Gastrointest. Liver Physiol. 297:G781-G791. https://doi.org/10 .1152/ajpgi.90605.2008.

Allen, M. S., B. J. Bradford, and M. Oba. 2009. The hepatic oxidation theory of the control of feed intake and its application to ruminants. J. Anim. Sci. 87:3317-3334. https://doi.org/10.2527/ jas.2009-1779.

Ansia, I., Y. Ohta, T. Fujieda, and J. K. Drackley. 2017. Effects of abomasal infusions of amino acids or glucose on energy and protein metabolism during an induced negative energy balance. J. Dairy Sci. 100(Suppl. 2):405-406. (Abstr.)

AOAC International. 2000. Official Methods of Analysis. 17th ed. AOAC Int.

AOAC International. 2002. Official Methods of Analysis. 17th ed. 1st reversion. AOAC Int.

AOAC International. 2006. Official Methods of Analysis. 18th ed. AOAC Int.

Aschenbach, J. R., N. B. Kristensen, S. S. Donkin, H. M. Hammon, and G. B. Penner. 2010. Gluconeogenesis in dairy cows: The secret of making sweet milk from sour dough. IUBMB Life 62:869-877. https://doi.org/10.1002/iub.400.

Baumgard, L. H., R. J. Collier, and D. E. Bauman. 2017. A 100-year review: Regulation of nutrient partitioning to support lactation. J. Dairy Sci. 100:10353-10366. https://doi.org/10.3168/jds.2017 -13242 .

Bernard, J. K. 1997. Milk production and composition responses to the source of protein supplements in diets containing wheat middlings. J. Dairy Sci. 80:938-942. https://doi.org/10.3168/jds .S0022-0302(97)76017-X.

Berthiaume, R., P. Dubreuil, and M. Stevenson. 2001. Intestinal disappearance and mesenteric and portal appearance of amino acids in dairy cows fed ruminally protected methionine. J. Dairy Sci. 84:194-203. https://doi.org/10.3168/jds.S0022-0302(01)74469-4.

Bertoni, G., and E. Trevisi. 2013. Use of the liver activity index and other metabolic variables in the assessment of metabolic health in dairy herds. Vet. Clin. North Am. Food Anim. Pract. 29:413-431. https://doi.org/10.1016/j.cvfa.2013.04.004.

Bradford, B. J., K. Yuan, J. K. Farney, L. K. Mamedova, and A. J. Carpenter. 2015. Invited review: Inflammation during the transi- tion to lactation: New adventures with an old flame. J. Dairy Sci. 98:6631-6650. https://doi.org/10.3168/jds.2015-9683.

Burrin, D. G., and B. Stoll. 2009. Metabolic fate and function of dietary glutamate in the gut. Am. J. Clin. Nutr. 90:850S-856S. https://doi.org/10.3945/ajcn.2009.27462Y.

Canadian Council on Animal Care. 2009. Guidelines on the care and use of farm animals in research, teaching and testing. Canadian Council on Animal Care.

Carder, E. G., and W. P. Weiss. 2017. Short- and longer-term effects of feeding increased metabolizable protein with or without an altered amino acid profile to dairy cows immediately postpartum. J. Dairy Sci. 100:4528-4538.

Ceciliani, F., J. J. Ceron, P. D. Eckersall, and H. Sauerwein. 2012. Acute phase proteins in ruminants. J. Proteomics 75:4207-4231. https://doi.org/10.1016/j.jprot.2012.04.004.

Clemmons, D. R., and L. E. Underwood. 1991. Nutritional regulation of IGF-I and IGF binding proteins. Annu. Rev. Nutr. 11:393-412. https://doi.org/10.1146/annurev.nu.11.070191.002141.

Cochran, R. C., D. C. Adams, J. D. Wallace, and M. L. Galyean. 1986. Predicting digestibility of different diets with internal markers: Evaluation of four potential markers. J. Anim. Sci. 63:1476-1483. https://doi.org/10.2527/jas1986.6351476x.

Doepel, L., M. Lessard, N. Gagnon, G. E. Lobley, J. F. Bernier, P. Dubreuil, and H. Lapierre. 2006. Effect of postruminal glutamine supplementation on immune response and milk production in dairy cows. J. Dairy Sci. 89:3107-3121.

Drackley, J. K. 1999. Biology of dairy cows during the transition period: The final frontier? J. Dairy Sci. 82:2259-2273. https://doi .org/10.3168/jds.S0022-0302(99)75474-3.

El-Kadi, S. W., R. L. Baldwin, K. R. McLeod, N. E. Sunny, and B. J. Bequette. 2009. Glutamate is the major anaplerotic substrate in the tricarboxylic acid cycle of isolated rumen epithelial and duodenal mucosal cells from beef cattle. J. Nutr. 139:869-875. https:/ /doi.org/10.3945/jn.108.103226.

Elsabagh, M., M. Ishikake, Y. Sakamoto, A. Haruno, M. Miura, T. Fujieda, T. Obitsu, and T. Sugino. 2018. Postruminal supply of amino acids enhances ghrelin secretion and lipid metabolism in feed-deprived sheep. Anim. Sci. J. 89:1663-1672. https://doi.org/ 10.1111/asj.13114.

Emmanuel, D. G. V., S. M. Dunn, and B. N. Ametaj. 2008. Feeding high proportions of barley grain stimulates an inflammatory response in dairy cows. J. Dairy Sci. 91:606-614. https://doi.org/10 $.3168 /$ jds.2007-0256.

Engelking, L. E., T. Matsuba, K. Inouchi, T. Sugino, and M. Oba. 2020. Effects of feeding hay and calf starter as a mixture or as separate components to Holstein calves on intake, growth, and blood metabolite and hormone concentrations. J. Dairy Sci. 103:44234434. https://doi.org/10.3168/jds.2019-17676.

Giallongo, F., M. T. Harper, J. Oh, J. C. Lopes, H. Lapierre, R. A. Patton, C. Parys, I. Shinzato, and A. N. Hristov. 2016. Effects of rumen-protected methionine, lysine, and histidine on lactation performance of dairy cows. J. Dairy Sci. 99:4437-4452. https://doi .org/10.3168/jds.2015-10822.

Giallongo, F., M. T. Harper, J. Oh, C. Parys, I. Shinzato, and A. N. Hristov. 2017. Histidine deficiency has a negative effect on lactational performance of dairy cows. J. Dairy Sci. 100:2784-2800. https://doi.org/10.3168/jds.2016-11992.

Giallongo, F., A. N. Hristov, J. Oh, T. Frederick, H. Weeks, J. Werner, H. Lapierre, R. A. Patton, A. Gehman, and C. Parys. 2015. Effects of slow-release urea and rumen-protected methionine and histidine on performance of dairy cows. J. Dairy Sci. 98:3292-3308. https:/ /doi.org/10.3168/jds.2014-8791.

Goering, H. K., and P. J. Van Soest. 1970. Forage fiber analysis (apparatus, reagents, procedures, and some applications). Pages 1-20 in Agriculture Handbook 379. Agricultural Research Service, United States Department of Agriculture.

Hall, M. B. 2009. Determination of starch, including malt oligosaccharides, in animal feeds: Comparison of methods and a recommended method for AOAC collaborative study. J. AOAC Int. 92:42-49. https://doi.org/10.1093/jaoac/92.1.42. 
Heitmann, R. N., and E. N. Bergman. 1981. Glutamate interconversions and glucogenicity in the sheep. Am. J. Physiol. Endocrinol. Metab. 241:E465-E472. https://doi.org/10.1152/ajpendo.1981 .241.6.E465.

ISO-IDF (International Organization for Standardization and International Dairy Federation). 2013. Milk and liquid milk productsGuidelines for the application of mid-infrared spectrometry. ISO 9622|IDF 141:2013. International Organization for Standardization.

Jiao, N., Z. Wu, Y. Ji, B. Wang, Z. Dai, and G. Wu. 2015. L-Glutamate enhances barrier and antioxidative functions in intestinal porcine epithelial cells. J. Nutr. 145:2258-2264. https://doi.org/10 $.3945 /$ jn.115.217661.

Johnson, D. E., K. A. Johnson, and R. L. Baldwin. 1990. Changes in liver and gastrointestinal tract energy demands in response to physiological workload in ruminants. J. Nutr. 120:649-655. https: //doi.org/10.1093/jn/120.6.649.

Khafipour, E., D. O. Krause, and J. C. Plaizier. 2009a. A grain-based subacute ruminal acidosis challenge causes translocation of lipopolysaccharide and triggers inflammation. J. Dairy Sci. 92:10601070. https://doi.org/10.3168/jds.2008-1389.

Khafipour, E., D. O. Krause, and J. C. Plaizier. 2009b. Alfalfa pelletinduced subacute ruminal acidosis in dairy cows increases bacterial endotoxin in the rumen without causing inflammation. J. Dairy Sci. 92:1712-1724. https://doi.org/10.3168/jds.2008-1656.

Kim, J. J., and W. I. Khan. 2013. Goblet cells and mucins: Role in innate defense in enteric infections. Pathogens 2:55-70. https://doi .org/10.3390/pathogens2010055.

Knoblock, C. E., W. Shi, I. Yoon, and M. Oba. 2019. Effects of supplementing a Saccharomyces cerevisiae fermentation product during the periparturient period on the immune response of dairy cows fed fresh diets differing in starch content. J. Dairy Sci. 102:61996209. https://doi.org/10.3168/jds.2018-16224.

Kojima, M., H. Hosoda, Y. Date, M. Nakazato, H. Matsuo, and K. Kangawa. 1999. Ghrelin is a growth-hormone-releasing acylated peptide from stomach. Nature 402:656-660. https://doi.org/10 $.1038 / 45230$.

Kvidera, S. K., M. J. Dickson, M. Abuajamieh, D. B. Snider, M. V. Sanz Fernandez, J. S. Johnson, A. F. Keating, P. J. Gorden, H. B. Green, K. M. Schoenberg, and L. H. Baumgard. 2017. Intentionally induced intestinal barrier dysfunction causes inflammation, affects metabolism, and reduces productivity in lactating Holstein cows. J. Dairy Sci. 100:4113-4127. https://doi.org/10.3168/jds .2016-12349.

Lee, C., A. N. Hristov, T. W. Cassidy, K. S. Heyler, H. Lapierre, G. A. Varga, M. J. de Veth, R. A. Patton, and C. Parys. 2012. Rumenprotected lysine, methionine, and histidine increase milk protein yield in dairy cows fed a metabolizable protein-deficient diet. J. Dairy Sci. 95:6042-6056. https://doi.org/10.3168/jds.2012-5581.

Littell, R. C., G. A. Milliken, W. W. Stroup, and R. D. Wolfinger. 1996. SAS system for mixed models. SAS Inst., Inc.

McCabe, C. J., and J. P. Boerman. 2020. Quantifying protein mobilization in dairy cows during the transition period. Appl. Anim. Sci. 36:389-396. https://doi.org/10.15232/aas.2019-01929.

Miyazawa, Y., M. Miura, T. Fujieda, I. Shinzato, S. W. Fessenden, and M. D. Stern. 2014. A three-step in vitro procedure for evaluating rumen-protected lysine products. J. Dairy Sci. 97(E-Suppl. 1):756.

NRC. 2001. Nutrient Requirements for Dairy Cattle. 7 th rev. ed. Natl. Acad. Press.

Pearce, S. C., V. Mani, T. E. Weber, R. P. Rhoads, J. F. Patience, L. H. Baumgard, and N. K. Gabler. 2013. Heat stress and reduced plane of nutrition decreases intestinal integrity and function in pigs. J. Anim. Sci. 91:5183-5193. https://doi.org/10.2527/jas.2013 -6759 .

Plaizier, J. C., M. D. Mesgaran, H. Derakhshani, H. Golder, E. Khafipour, J. L. Kleen, I. Lean, J. Loor, G. Penner, and Q. Zebeli. 2018.
Review: Enhancing gastrointestinal health in dairy cows. Animal 12:s399-s418.

Reece, W. O., H. H. Errickson, J. P. Goff, and E. E. Uemura. 2015. Duke's Physiology of Domestic Animals. Wiley-Blackwell, Oxford.

Reeds, P. J., D. G. Burrin, B. Stoll, and F. Jahoor. 2000. Intestinal glutamate metabolism. J. Nutr. 130:978S-982S. https://doi.org/ 10.1093/jn/130.4.978S.

Reynolds, C. K., B. Dürst, B. Lupoli, D. J. Humphries, and D. E. Beever. 2004. Visceral tissue mass and rumen volume in dairy cows during the transition from late gestation to early lactation. J. Dairy Sci. 87:961-971. https://doi.org/10.3168/jds.S0022 -0302(04)73240-3.

Rezaei, R., D. A. Knabe, C. D. Tekwe, S. Dahanayaka, M. D. Ficken, S. E. Fielder, S. J. Eide, S. L. Lovering, and G. Wu. 2013. Dietary supplementation with monosodium glutamate is safe and improves growth performance in postweaning pigs. Amino Acids 44:911-923. https://doi.org/10.1007/s00726-012-1420-x.

Stern, M. D., K. A. Santos, and L. D. Satter. 1985. Protein degradation in rumen and amino acid absorption in small intestine of lactating dairy cattle fed heat-treated whole soybeans. J. Dairy Sci. 68:45-56. https://doi.org/10.3168/jds.S0022-0302(85)80796-7.

Van Der Schoor, S. R. D., P. J. Reeds, B. Stoll, J. F. Henry, J. R Rosenberger, D. G. Burrin, and J. B. van Goudoever. 2002. The high metabolic cost of a functional gut. Gastroenterology 123:1931-1940. https://doi.org/10.1053/gast.2002.37062.

Van Soest, P. J., J. B. Robertson, and B. A. Lewis. 1991. Methods for dietary fiber, neutral detergent fiber, and nonstarch polysaccharides in relation to animal nutrition. J. Dairy Sci. 74:3583-3597. https://doi.org/10.3168/jds.S0022-0302(91)78551-2.

Waltz, D. M., M. D. Stern, and D. J. Illg. 1989. Effect of ruminal protein degradation of blood meal and feather meal on the intestinal amino acid supply to lactating cows. J. Dairy Sci. 72:1509-1518. https://doi.org/10.3168/jds.S0022-0302(89)79261-4.

West, H. J. 1990. Effect on liver function of acetonaemia and the fat cow syndrome in cattle. Res. Vet. Sci. 48:221-227. https://doi.org/ 10.1016/S0034-5288(18)30994-9.

Wildman, E. E., G. M. Jones, P. E. Wagner, R. L. Boman, H. F. Troutt Jr., and T. N. Lesch. 1982. A dairy cow body condition scoring system and its relationship to selected production characteristics. J. Dairy Sci. 65:495-501. https://doi.org/10.3168/jds .S0022-0302(82)82223-6.

Wu, G. 2013. Amino Acids: Biochemistry and Nutrition. CRC Press.

Wu, X., Y. Zhang, Z. Liu, T. J. Li, and Y. L. Yin. 2012. Effects of oral supplementation with glutamate or combination of glutamate and N-carbamylglutamate on intestinal mucosa morphology and epithelium cell proliferation in weanling piglets. J. Anim. Sci. 90(suppl_4):337-339. https://doi.org/10.2527/jas.53752.

Yin, J., M. Liu, W. Ren, J. Duan, G. Yang, Y. Zhao, R. Fang, L. Chen, T. Li, and Y. Yin. 2015. Effects of dietary supplementation with glutamate and aspartate on diquat-induced oxidative stress in piglets. PLoS One 10:e0122893. https://doi.org/10.1371/journal .pone.0122893.

Zang, Y., L. H. P. Silva, M. Ghelichkhan, M. Miura, N. L. Whitehouse, M. L. Chizzotti, and A. F. Brito. 2019. Incremental amounts of rumen-protected histidine increase plasma and muscle histidine concentrations and milk protein yield in dairy cows fed a metabolizable protein-deficient diet. J. Dairy Sci. 102:4138-4154. https:// doi.org/10.3168/jds.2018-15780.

\section{ORCIDS}

S. Hisadomi $\odot$ https://orcid.org/0000-0001-6599-1245

T. Sugino $\odot$ https://orcid.org/0000-0001-5502-3451

M. Oba ৫ https://orcid.org/0000-0001-8057-3500 